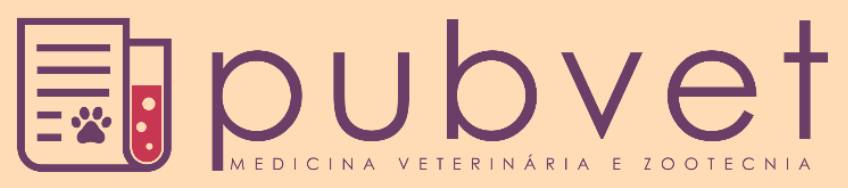

https://doi.org/10.31533/pubvet.v15n010a940.1-7

\title{
Forage productivity and chemical composition of Megathyrsus maximus cv. Tamani under defoliations regimes
}

\author{
Newton de Lucena Costa $1^{*}$, Liana Jank ${ }^{2}$, João Avelar Magalhães ${ }^{3}$, Antônio Neri \\ Azevedo Rodrigues ${ }^{4}$, Amaury Burlamaqui Bendahan ${ }^{\ominus}$, Vicente Gianluppi ${ }^{1}{ }^{\ominus}$, Braz \\ Henrique Nunes Rodrigues ${ }^{\circ}$, Francisco José de Seixas Santos ${ }^{\bullet} 6$
}

\author{
${ }^{I}$ Eng. Agr., D.Sc., Pesquisador da Embrapa Roraima, Boa Vista, RR. \\ ${ }^{2}$ Eng. Agr., Ph.D., Pesquisadora da Embrapa Gado de Corte, Campo Grande, MS. \\ ${ }^{3}$ Méd. Vet., Pesquisador da Embrapa Meio-Norte, Parnaíba, PI. \\ ${ }^{4}$ Eng. Agr., D.Sc., Professor do Instituto Federal de Rondônia, Colorado do Oeste, RO. \\ ${ }^{5}$ Eng. Agrícola, D.Sc., Pesquisador da Embrapa Meio-Norte, Parnaíba, PI. \\ ${ }^{6}$ Eng. Agr., D.Sc., Pesquisador da Embrapa Meio-Norte, Parnaiba, PI. \\ *Autor para correspondência, E-mail: newton.lucena-costa@embrapa.br
}

\begin{abstract}
The effects of defoliation frequency (21, 28, 35 and 42 days) and defoliation intensity $(20,30$ and $40 \mathrm{~cm}$ above the ground) on green dry matter (GDM) yield, and chemical composition of Megathyrsus maximus cv. Tamani were evaluated under natural field conditions at the Roraima's savannas. Defoliation regimes affect productivity and chemical composition of M. maximus cv. Tamani forage. The decrease in the pasture defoliation frequency and intensity improved the accumulation of forage, however it reduces the tissue concentrations of $\mathrm{N}, \mathrm{P}, \mathrm{Ca}, \mathrm{Mg}$ and $\mathrm{K}$. Irrespective of defoliation frequencies, the highest levels of $\mathrm{N}\left(25.31 \mathrm{~g} \mathrm{~kg}^{-1}\right), \mathrm{P}\left(2.11 \mathrm{~g} \mathrm{~kg}^{-1}\right), \mathrm{Mg}\left(2.78 \mathrm{~g} \mathrm{~kg}^{-1}\right)$ and $\mathrm{K}$ $\left(21.13 \mathrm{~g} \mathrm{~kg}^{-1}\right)$ were recorded for the defoliation intensity at $40 \mathrm{~cm}$ above the ground, except for $\mathrm{Ca}\left(4.31 \mathrm{~g} \mathrm{~kg}^{-1}\right)$, where the greatest concentration was obtained with defoliations at 30 $\mathrm{cm}$ above the ground. The use of defoliation frequency around 32 days and defoliation intensity of $28 \mathrm{~cm}$ above the ground can be considered adequate for the management of pastures of $M$. maximus cv. Tamani, in order to provides higher forage productivity and quality, regrowth vigor, larger efficiency of forage utilization, greater tissue renewal and canopy structure more favorable to grazing.
\end{abstract}

Keywords: Calcium, green dry matter, magnesium, nitrogen, phosphorus, potassium

\section{Produtividade e composição química da forragem de Megathyrsus maximus cv. Tamani sob regimes de desfolhação}

Resumo. O efeito da frequência de desfolhação (21, 28, 35 e 42 dias) e intensidade de desfolhação (20, 30 e $40 \mathrm{~cm}$ acima do solo) sobre o rendimento e composição química da forragem de Megathyrsus maximus cv. Tamani foi avaliado em condições de campo nos cerrados de Roraima. Os regimes de desfolhação afetaram a produtividade e a composição química da forragem da gramínea. A redução na frequência e intensidade de desfolhação resultou em maiores rendimentos de matéria seca verde, contudo, implicou em decréscimos significativos dos teores de nitrogênio $(\mathrm{N})$, fósforo $(\mathrm{P})$, cálcio $(\mathrm{Ca})$, magnésio $(\mathrm{Mg})$ e potássio $(\mathrm{K})$. Independentemente das frequências de desfolhação, as maiores concentrações de $\mathrm{N}\left(25,31 \mathrm{~g} \mathrm{~kg}^{-1}\right), \mathrm{P}\left(2,11 \mathrm{~g} \mathrm{~kg}^{-1}\right), \mathrm{Mg}\left(2,78 \mathrm{~g} \mathrm{~kg}^{-1}\right)$ e $\mathrm{K}\left(21,13 \mathrm{~g} \mathrm{~kg}^{-1}\right)$ na forragem foram registradas com cortes a $40 \mathrm{~cm}$ acima do solo, exceto para o $\mathrm{Ca}\left(4,31 \mathrm{~g} \mathrm{~kg}^{-1}\right)$ que apresentou maior teor com cortes a $30 \mathrm{~cm}$ acima do solo. Pastagens de M. maximus cv. Tamani manejadas sob frequência de desfolhação em torno de 32 dias e intensidade de desfolhação de $28 \mathrm{~cm}$ acima do solo proporcionam maior produtividade e qualidade da forragem, maior 
eficiência de sua utilização, maior renovação de tecidos e estrutura do dossel mais favorável ao pastejo.

Palavras-chave: Cálcio, matéria seca verde, magnésio, nitrogênio, fósforo, potássio

\title{
Productividad y composición química del forraje de Megathyrsus maximus cv. Tamani bajo regímenes de defoliación
}

\begin{abstract}
Resumen. El efecto de la frecuencia de defoliación (21, 28, 35 y 42 días) y la intensidad de defoliación (20,30 y $40 \mathrm{~cm}$ por encima del suelo) sobre el rendimiento de forraje y la composición química de Megathyrsus maximus cv. Tamani se evaluó en condiciones de campo en las sabanas de Roraima. Los regímenes de defoliación afectaron la productividad y la composición química del forraje de la gramínea. La reducción en la frecuencia e intensidad de la defoliación resultó en mayores rendimientos de materia seca verde, sin embargo, implicó disminuciones significativas en los niveles de nitrógeno $(\mathrm{N})$, fósforo $(\mathrm{P})$, calcio $(\mathrm{Ca})$, magnesio $(\mathrm{Mg})$ y potasio $(\mathrm{K})$. Independientemente de las frecuencias de defoliación, las concentraciones más altas de $\mathrm{N}\left(25,31 \mathrm{~g} \mathrm{~kg}^{-1}\right), \mathrm{P}\left(2,11 \mathrm{~g} \mathrm{~kg}^{-1}\right), \mathrm{Mg}(2,78 \mathrm{~g}$ $\left.\mathrm{kg}^{-1}\right)$ y K $\left(21,13 \mathrm{~g} \mathrm{~kg}^{-1}\right)$ en el forraje se registraron con cortes a $40 \mathrm{~cm}$ por encima del suelo, excepto $\mathrm{Ca}\left(4,31 \mathrm{~g} \mathrm{~kg}^{-1}\right)$, que presentó el mayor contenido con cortes a $30 \mathrm{~cm}$ por encima del suelo. Pastizales de M. maximus cv. Tamani manejados bajo una frecuencia de defoliación alrededor de 32 días y una intensidad de defoliación de $28 \mathrm{~cm}$ sobre el suelo proporcionan mayor productividad y calidad del forraje, mayor eficiencia de su uso, mayor renovación de tejidos y estructura del dosel más favorable al pastoreo.
\end{abstract}

Palabras clave: Calcio, materia seca verde, magnesio, nitrógeno, fósforo, potasio

\section{Introduction}

In Roraima, cattle ranching is a of the main economic activities and the cultivated pastures represent the main forage resource for the feeding of the herds. The use of continuous grazing or minimum rest periods, high intensities defoliation and non-replacement of nutrients removed via animal production are factors that contribute to low availability and quality of forage, with negative effects on the zootechnical performance of animals (Costa et al., 2007). Productivity and longevity of forage grasses derive from their capacity reconstitution and maintenance of the leaf area after defoliation, which affects the structure of the canopy, determining its speed of growth (Pereira, 2013). The accumulation of forage is closely related to the stadium of grass growth as a consequence of morphological and physiological changes that change the balance between production and senescence of tissues, with reflexes in the chemical composition, regrowth capacity andpasture persistence (Costa et al., 2014; Nabinger \& Carvalho, 2009).

The central point of grazing management is to mediate the plant-animal encounter and determine the efficiency between the growth of the plant, its consumption and animal production to keep the production system (Hodgson, 1990). The balance between productivity and quality must be achieved, aiming to ensure the nutritional requirements of the animals and at the same time maximizing the efficiency of the production, use and conversion processes of the forage produced. The grassland management - defoliation frequency and intensity - promove conditions differences in the structure of the pasture that affect the process of defoliation by the animal and modify the growth dynamics of the pasture with influences on the biomass flows (Cavalli, 2016; Nascimento, 2014). Defoliation intensity represents the proportion of tissue plant removed by the animal in comparison to that made available for grazing, impacting the leaf area photosynthetically active remnant, the remobilization of organic reserves and the removal of apical meristems (Lemaire et al., 2011).

Pasture productivity is strongly influenced by environmental conditions (temperature, light, water and soil fertility) and management practices, while its longevity, among other factors, results from the ability to reconstitute and maintain the leaf area after defoliation, which affects the structure of the canopy, determining its growth speed, forage accumulation, chemical composition and persistence (Almeida, 2015; Nabinger \& Pontes, 2002; Souza, 2018). 
The defoliation frequency affects the rest period available for pasture growth and significantly influences its productivity, chemical composition, regrowth capacity and persistence. Frequent grazing provides greater forage yields, however, concomitantly, there are marked decreases in its chemical composition, with greater accumulation of fibrous material, decrease in the leaf/stem ratio and, consequently, less forage intake by animals (Lemaire et al., 2011).

In this work were avaluated the effects of defoliation frequency and itensity on forage accumulation and chemical composition of Megathyrsus maximus cv. Tamani in the Roraima's savannas.

\section{Material ans methods}

The trial was conducted at the Embrapa Roraima Experimental Field, located in Boa Vista, from May to September 2016, which corresponded to an accumulated precipitation of 1,416 $\mathrm{mm}$ and an average monthly temperature of $24.79^{\circ} \mathrm{C}$. The soil of the experimental area is a Yellow Latosol, medium texture, savanna phase, with the following chemical characteristics, at a depth of $0-20 \mathrm{~cm}: \mathrm{pH}_{\mathrm{H} 2 \mathrm{O}}=5.8 ; \mathrm{P}=15.8$ $\mathrm{mg} / \mathrm{kg} ; \mathrm{Ca}+\mathrm{Mg}=1.19 \mathrm{cmol}_{\mathrm{c}} \cdot \mathrm{dm}^{-3} ; \mathrm{K}=0.022 \mathrm{cmol}_{\mathrm{c}} \cdot \mathrm{dm}^{-3}$ and $\mathrm{Al}=0.13 \mathrm{cmol}_{\mathrm{c}} \cdot \mathrm{dm}^{-3}$.

The experimental design was entirely randomized with three replications. The treatments consisted of four defoliation frequencies $(21,28,35$ and 42 days) and three defoliation intensities $(20,30$ and 40 $\mathrm{cm}$ above the ground). The establishment fertilization consisted of the application of $90 \mathrm{~kg}$ of N ha-1, 50 $\mathrm{kg}$ of $\mathrm{P}_{2} \mathrm{O} 5 \mathrm{ha}^{-1}$ and $60 \mathrm{~kg}$ of $\mathrm{K}_{2} \mathrm{O} \mathrm{ha}^{-1}$, in the form of urea, triple superphosphate and potassium chloride, respectively. The nitrogen fertilization was divided in two times, being $1 / 3$ when planting, and $2 / 3$ at 21 days. The plots measured $2.0 \times 2.0 \mathrm{~m}$, with a useful area of $1.0 \mathrm{~m}^{2}$. During the experimental period were made 6, 5, 4 and 3 cuts, respectively for defoliation frequencies of 21, 28, 35 and 42 days.

The evaluated parameters were green dry matter yield (GDM), nitrogen $(\mathrm{N})$, phosphorus $(\mathrm{P})$, calcium $(\mathrm{Ca})$, magnesium $(\mathrm{Mg})$ and potassium $(\mathrm{K})$ contents. The $\mathrm{N}$ levels were analyzed according to the procedures described by Silva \& Queiroz (2002); while the levels of P, Ca, Mg and K were determined according to the methodology described by Silva (2009). The levels of P and K were quantified after nitroperchloric digestion. $\mathrm{P}$ was determined by colorimetry; $\mathrm{K}$ by flame photometry and $\mathrm{Ca}$ and $\mathrm{Mg}$ concentrations by atomic absorption spectrophotometry.

The data were subjected to analysis of variance and regression considering the significance level of $5 \%$ probability. In order to estimate the response of the parameters evaluated to the defoliation frequency and intensity, the choice of regression models was based on the significance of the linear and quadratic coefficients, using the Student's " $t$ " test, at the level of 5\% probability.

\section{Results and discussion}

The GDM yields were affected $(\mathrm{P}<0.05)$ by the interaction between frequencies and intensities of defoliation. The effect of the defoliation intensity was adjusted to the quadratic regression model $(\mathrm{Y}=$ $\left.1,481+204.85 \mathrm{X}-3.1752 \mathrm{X}^{2}\left[\mathrm{R}^{2}=0.94\right]\right)$ and the maximum value was estimated at $32.2 \mathrm{~cm}$ above the ground (Table 1). For M. maximus cv. Tamani pastures, Costa et al. (2020a) estimated that $28.2 \mathrm{~cm}$ above the ground was the best defoliation intensity, which was correlated to the higher tillering and higher rates of leaf appearance and expansion and lower leaf senescence. For pastures of M. maximus cvs. Tamani and Kenya, Tesk et al. (2020) suggest the use of grazing intensities of 25 and $35 \mathrm{~cm}$ above the ground, respectively, which were correlated to high forage yields and higher recovery speed after the grazing.

Table 1. Gren dry matter $\left(\mathrm{kg} \mathrm{ha}^{-1}\right)$ yield of Megathyrsus maximus $\mathrm{cv}$. Tamani, as affected by defoliation regimes

\begin{tabular}{cccccc}
\hline Defoliation & \multicolumn{4}{c}{ Defoliation Frequency (days) } & \multirow{2}{*}{ Regression Equation } \\
\cline { 2 - 4 } Intensity $(\mathrm{cm})$ & 21 & 28 & 35 & 42 & \\
\hline 20 & 2,051 & 2,756 & 3,655 & 3,433 & $\mathrm{Y}=3,680+368.94 \mathrm{X}-4.7143 \mathrm{X}^{2}\left(\mathrm{R}^{2}=0,91\right)$ \\
30 & 2,354 & 3,359 & 4,205 & 3,826 & $\mathrm{Y}=5,505+520.03 \mathrm{X}-7.0621 \mathrm{X}^{2}\left(\mathrm{R}^{2}=0,93\right)$ \\
40 & 2,298 & 3,101 & 3,911 & 3,737 & $\mathrm{Y}=3,686+387.28 \mathrm{X}-4.9897 \mathrm{X}^{2}\left(\mathrm{R}^{2}=0,97\right)$ \\
\hline
\end{tabular}

Defoliation implies a rapid decline in the amount of soluble carbohydrates available for the growth of grass roots, as a consequence of the reduction in its photosynthetic rate as a whole and preferential 
allocation of carbon to the plant parts in order to restore its leaf area (Costa et al., 2008; Lemaire et al., 2011; Pereira et al., 2011; Silva, 2019). Costa et al. (2020b) found that the best defoliation frequency for pastures of M. maximus cv. Tamani was estimated at 38.4 days, which showed a high correlation with tiller density and leaf area index and lower leaf senescence.

The GDM yields for all defoliation levels were higher than suggested by Minson (2012) as a minimum forage limit available in tropical grass pastures $\left(2,000 \mathrm{~kg} \mathrm{ha}^{-1}\right)$, so as not to restrict access and intake voluntary forage by animals. Based on this premise, Barbosa et al. (2007) found an interaction between post-grazing residue height and defoliation frequency in pastures of $M$. maximus cv. Tanzania1, with resting periods of 31 to 35 days and 24 to 27 days, respectively, for 25 and $50 \mathrm{~cm}$ of residue, which were correlated with $90 \%$ of light interception by the pasture canopy.

The effect of the defoliation frequency on GDM yields was adjusted to the quadratic regression model and the maximum values were estimated at $39.9 ; 36.1$ and 38.2 days, respectively to defoliation intensities of 20,30 and $40 \mathrm{~cm}$ above the ground (Table 1). The data indicate that the greater the defoliation intensity, greater should be the time available for adequate pasture recovery. In the Rondônia's savannas, for pastures of M. maximus cvs. Centenário and Massai, Costa et al. (2007) reported higher forage yields for defoliation frequencies varying between 21 and 28 days. For higher defoliation frequencies, the regrowth speed showed a high correlation with the preservation of apical meristems, whose preservation stimulates the formation of photosynthetic tissues through the expansion of new leaves, while the removal of apical meristems implies slower growth and originates the from the development of buds, notably of basal origin, for the production of new leaves (Barbosa et al., 2002; Cunha et al., 2012; Difante et al., 2011; Pena et al., 2009).

The adequate interval between grazing of M. maximus cv. Tanzania- 1 should not be established alone on the basis of the GDM accumulation rate, requiring knowledge about the interactions between stem production and grazing efficiency, consumption and forage quality (Santos et al., 2012; Santos et al., 2003). The authors recommend 38-day rest periods from October to April; 28 days in the grass reproductive phase (April and May) and about 48 days between May and September. In pastures of $M$. maximus cv. Aruana, the prolongation of the defoliation frequency negatively affected the structure of its canopy, reducing the leaf/stem ratio and the tillers population, however, morphological and structural adaptations of the forage canopy allowed satisfactory regrowth under management in which the frequency between defoliation allows 4.0 new tiller $^{-1}$ leaves to appear during the rainy season. The adequate defoliation frequency in grass-Tanzania-1 pastures should not exceed 35 days and coincide with the appearance of at least 3.5 fully expanded leaves per tiller (Ferlin et al., 2006; Gomide et al., 2007; Pena et al., 2009).

Defoliation frequencies affected negatively and linearly the N, P, Ca Mg and K concentrations (Table 2), showing a dilution effect with a decrease in the frequency of defoliation of the grass. Irrespective of defoliation frequencies, the highest levels of $\mathrm{N}\left(25.31 \mathrm{~g} \mathrm{~kg}^{-1}\right), \mathrm{P}\left(2.11 \mathrm{~g} \mathrm{~kg}^{-1}\right), \mathrm{Mg}\left(2.78 \mathrm{~g} \mathrm{~kg}^{-1}\right)$ and $\mathrm{K}$ $\left(21,13 \mathrm{~g} \mathrm{~kg}^{-1}\right)$ were recorded for the defoliation intensity at $40 \mathrm{~cm}$ above the ground, except for $\mathrm{Ca}(4.31$ $\mathrm{g} \mathrm{kg}^{-1}$ ), where the greatest concentration was obtained with defoliations at $30 \mathrm{~cm}$ above the ground. The concentrations estimated in this work were similar to or higher than those reported by Costa et al. (2007) for pastures of M. maximus cvs. Aruana, Atlas, Massai and Vencedor, submitted to different defoliation frequencies. For $\mathrm{P}, \mathrm{Ca}, \mathrm{Mg}$ and $\mathrm{K}$, the levels obtained with rest periods of up to 21 days were higher than the internal critical level determined by Costa et al. (2006) for M. maximus cv. Centenário (1.71, $3.38,2.44$ and $19.27 \mathrm{~g} \mathrm{~kg}^{-1}$, respectively for $\mathrm{P}, \mathrm{Ca}, \mathrm{Mg}$ and $\left.\mathrm{K}\right)$. However, Oliveira et al. (2009) evaluated pastures of M. maximus cv. Mombaça and reported maximum concentrations of $\mathrm{N}, \mathrm{P}, \mathrm{K}, \mathrm{Ca}$ and $\mathrm{Mg}$, respectively at 104, 102, 105, 68 and 78 days of defoliation frequency.

Defoliation frequency affect grass chemical composition negatively and linearly, as a consequence of the potentiation of leaf senescence processes (Table 2). Leaf senescence expresses the competition for metabolites and nutrients between old and growing young leaves, which reduces the availability of good quality forage (Lemaire et al., 2011; Santos et al., 2004). Senescence reflects the natural physiological process that characterizes the last stage of leaf development, started after its complete expansion and progressively accentuated with the increase in leaf area, due to the shading of the leaves inserted in the lower portion and the low supply of photosynthetically active radiation, characterized by 
intense competition for light, nutrients and water between the different strata of the plant (Nabinger \& Pontes, 2002). The tiller when reaching a certain number of live leaves tillers ${ }^{-1}$ (NLLT) establishes the balance between the leaf appearance rate and the senescence of the leaves that have exceeded their life span, so for the appearance of a new leaf it implies the senescence of the previous leaf, keeping the NLLT relatively constant (Lemaire et al., 2011; Martuscello et al., 2019; Pereira, 2013).

Table 2. Nitrogen, phosphorus, calcium, magnesium and potassium concentrations of Megathyrsus maximus cv. Tamani, as affected by defoliation regimes

\begin{tabular}{|c|c|c|c|c|c|}
\hline \multirow{2}{*}{$\begin{array}{l}\text { Defoliation } \\
\text { Intensity }(\mathrm{cm})\end{array}$} & \multicolumn{4}{|c|}{ Defoliation Frequency (days) } & \multirow{2}{*}{-Regression Equation } \\
\hline & 21 & 28 & 35 & 42 & \\
\hline \multicolumn{6}{|c|}{ Nitrogen $\left(\mathrm{g} \mathrm{kg}^{-1}\right)$} \\
\hline 20 & 25.21 & 24.33 & 22.76 & 19.65 & $Y=31.21-0.2607 \times\left(r^{2}=0,96\right)$ \\
\hline 30 & 26.88 & 25.14 & 23.98 & 20.75 & $Y=32.98-0.2793 \times\left(r^{2}=0.89\right)$ \\
\hline 40 & 28.15 & 26.43 & 24.57 & 22.06 & $\mathrm{Y}=34.36-0.2876 \times\left(\mathrm{r}^{2}=0,92\right)$ \\
\hline \multicolumn{6}{|c|}{ Phosphorus $\left(\mathrm{g} \mathrm{kg}^{-1}\right)$} \\
\hline 20 & 2.02 & 1.89 & 1.73 & 1.62 & $\mathrm{Y}=2.47-0.0194 \times\left(\mathrm{r}^{2}=0,97\right)$ \\
\hline 30 & 2.21 & 1.96 & 1.91 & 1.82 & $\mathrm{Y}=2.52-0.0176 \times\left(\mathrm{r}^{2}=0.93\right)$ \\
\hline 40 & 2.36 & 2.13 & 2.01 & 1.97 & $\mathrm{Y}=2.69-0.0184 \times\left(\mathrm{r}^{2}=0.95\right)$ \\
\hline \multicolumn{6}{|c|}{ Calcium $\left(\mathrm{g} \mathrm{kg}^{-1}\right)$} \\
\hline 20 & 4.71 & 4.08 & 3.86 & 3.77 & $\mathrm{Y}=5.47-0.0434 \times\left(\mathrm{r}^{2}=0,91\right)$ \\
\hline 30 & 4.84 & 4.23 & 4.17 & 3.98 & $Y=5.49-0.0377 \times\left(r^{2}=0.95\right)$ \\
\hline 40 & 4.91 & 4.33 & 4.03 & 3.75 & $\mathrm{Y}=5.95-0.0543 \times\left(\mathrm{r}^{2}=0.90\right)$ \\
\hline \multicolumn{6}{|c|}{ Magnesium $\left(\mathrm{g} \mathrm{kg}^{-1}\right)$} \\
\hline 20 & 2.57 & 2.13 & 2.02 & 1.89 & $\mathrm{Y}=3.12-0.0307 \times\left(\mathrm{r}^{2}=0,94\right)$ \\
\hline 30 & 2.93 & 2.51 & 2.43 & 2.22 & $\mathrm{Y}=3.51-0.0316 \times\left(\mathrm{r}^{2}=0.91\right)$ \\
\hline 40 & 3.12 & 2.90 & 2.66 & 2.45 & $\mathrm{Y}=3.81-0.0323 \times\left(\mathrm{r}^{2}=0.92\right)$ \\
\hline \multicolumn{6}{|c|}{ Potassium $\left(\mathrm{g} \mathrm{kg}^{-1}\right)$} \\
\hline 20 & 20.45 & 18.98 & 17.71 & 17.32 & $\mathrm{Y}=23.39-0.1509 \times\left(\mathrm{r}^{2}=0,93\right)$ \\
\hline 30 & 22.51 & 20.08 & 18.97 & 18.11 & $\mathrm{Y}=26.35-0.2044 \times\left(\mathrm{r}^{2}=0.94\right)$ \\
\hline 40 & 23.19 & 21.75 & 20.36 & 19.22 & $\mathrm{Y}=27.11-0.2876 \times\left(\mathrm{r}^{2}=0.88\right)$ \\
\hline
\end{tabular}

The leaf senescence reduces the quality of the forage, however it represents an important physiological process in the dynamics of the grass tissue flow, since about $35 ; 68 ; 86$ and $42 \%$ of N, P, $\mathrm{K}$ and $\mathrm{Mg}$, respectively, can be recycled from senescent leaves and used for the production of new leaf tissues (Costa et al., 2013; $\underline{\text { Sarmiento et al., 2006). }}$.

\section{Conclusions}

The forage yield and chemical composition of $M$. maximus $\mathrm{cv}$. Tamani were affect by defoliation regimes. The decrease in the pasture defoliation frequency and intensity improved the accumulation of forage, however it reduces the tissue concentrations of $\mathrm{N}, \mathrm{P}, \mathrm{Ca}, \mathrm{Mg}$ and $\mathrm{K}$.

The use of defoliation frequency around 32 days and defoliation intensity of $28 \mathrm{~cm}$ above the ground can be considered adequate for the management of pastures of M. maximus $\mathrm{cv}$. Tamani, in order to reconcile production, regrowth vigor and forage quality, greater tissue renewal and canopy structure more favorable to grazing.

\section{References}

Almeida, O. G. (2015). Morfogênese e produção de acessos de Panicum maximum. Monografia. (Bacharelado em Zootecnia). Universidade Federal de São João del Rei. 46f.

Barbosa, R. A., Nascimento Júnior, D., Euclides, V. P. B., Regazzi, A. J., \& Fonseca, D. M. (2002). Características morfogênicas e acúmulo de forragem do capim-Tanzânia (Panicum maximum Jacq. cv. Tanzânia) em dois resíduos forrageiros pós-pastejo. Revista Brasileira de Zootecnia, 31(2), 583593. http://dx.doi.org/10.1590/S1516-35982002000300007

Barbosa, R. A., Nascimento Júnior, D., Euclides, V. P. B., Silva, S. C., Zimmer, A. H., \& Torres Júnior, R. A. (2007). Capim-tanzânia submetido a combinações entre intensidade e freqüência de pastejo. Pesquisa Agropecuária Brasileira, 42(3), 329-340. http://dx.doi.org/10.1590/S0100204X2007000300005 
Cavalli, J. (2016). Estratégias de manejo do pastejo para Panicum maximum cvs. Quênia e Tamani. Universidade Federal de Mato Grosso. Monografia (Bacharelado em Zootecnia). 96f.

Costa, C. A. A., Andrade, A. C., Magalhães, J. A., Mehl, H. U., Rodrigues, B. H. N., da Silva, E. M., Bitencourt, A. B., Santos, F. J. S., \& Costa, N. L. (2014). Características agronômicas dos capins Digitaria sp. e Cynodon dactylon cv. Tifton-85 sob diferentes alturas de resíduo. PUBVET, 7(1), 1509.

Costa, N L, Jank, L., Magalhães, J. A., Azevedo, A. N., Rodrigues, A. B. B., Gianluppi, V., Nunes, B. H., \& Rodrigues, F. J. S. (2020a). Forage accumulation and morphogenetic and structural characteristics of Megathyrsus maximus cv. Tamani under defoliation intensities. PUBVET, 14(4). http://dx.doi.org/10.31533/pubvet.v14n4a553.1-7

Costa, N L, Jank, L., Magalhães, J. A., Rodrigues, A. N. A., Bendahan, A. B., Gianluppi, V., Rodrigues, B. H. N., \& Santos, F. J. S. (2020b). Productive performance, chemical composition and morphogenesis of Megathyrsus maximus cv. Tamani under rest periods. PUBVET, 14(4), 1-8. http://dx.doi.org/10.31533/pubvet.v14n4a554.1-8

Costa, N L, Magalhães, J. A., Pereira, R. G. A., Townsend, C. R., \& Oliveira, J. R. C. (2007). Considerações sobre o manejo de pastagens na Amazônia Ocidental. Revista do Conselho Federal de Medicina Veterinária, 40, 37-56.

Costa, N L, Paulino, V. T., Magalhães, J. A., Townsend, C. R., \& Pereira, R. G. A. (2008). Morfogênese de gramíneas forrageiras na Amazônia Ocidental. PUBVET, 2, 1-24.

Costa, N L, Moraes, A., Monteiro, A. L. G., Motta, A. C. V., Oliveira, R. A., \& Rodrigues, A. N. A. (2013). Forage productivity and morphogenesis of Axonopus aureus under different nitrogen fertilization rates. Revista Brasileira de Zootecnia, 42(8), 541-548. https://doi.org/10.1590/S151635982013000800002

Costa, N L, Townsend, C. R., \& Magalhães, J. A. (2006). Formação e manejo de pastagens na Amazônia do Brasil. Revista Electrónica de Veterinária, 7, 1-18.

Cunha, F. F., Ramos, M. M., Brasileiro, A. C. A., Rubens, O. A., Cóser, A. C., Martins, C. E., Cecon, P. R., \& Silva, A. R. A. (2012). Produtividade da Brachiaria brizantha cv. Xaraés em diferentes manejos e doses de adubação, períodos de descanso e épocas do ano. Idesia (Arica), 30(1), 75-82. http://dx.doi.org/10.4067/S0718-34292012000100009

Difante, G. S., Nascimento Júnior, D., Silva, S. C., Euclides, V. P. B., \& Montagner, D. B. (2011). Características morfogênicas e estruturais do capim-marandu submetido a combinações de alturas e intervalos de corte. Revista Brasileira de Zootecnia, 40(5), 955-963. http://dx.doi.org/10.1590/S01516-35982011000500003

Ferlin, M. B., Euclides, V. P. B., Lempp, B., Gonçalves, M. C., \& Cubas, A. C. (2006). Morfogênese e dinâmica do perfilhamento de Panicum maximum Jacq. cv. Tanzânia sob pastejo. Ciência e Agrotecnologia , 30, 344-352. https://doi.org/10.1590/S1413-70542006000200022

Gomide, C. A. M., Gomide, J. A., \& Alexandrino, E. (2007). Características estruturais e produção de forragem em pastos de capim-mombaça submetidos a períodos de descanso. Pesquisa Agropecuária Brasileira, 42(10), 1487-1494. http://dx.doi.org/10.1590/S0100-204X2007001000017

Hodgson, J. (1990). Grazing management. Science into practice. Longman Group UK Ltd. 203p.

Lemaire, G., Hodgson, J., \& Chabbi, A. (2011). Grassland productivity and ecosystem services. Wallingford, CABI. 297p.

Martuscello, J. A., Rios, J. F., Ferreira, M. R., Assis, J. A., Braz, T. G. S., \& Cunha, D. N. F. V. (2019). Produção e morfogênese de capim BRS Tamani sob diferentes doses de nitrogênio e intensidades de desfolhação. Boletim Da Indústria Animal, 76, 1-10. https://doi.org/10.17523/bia.2019.v76.e1441

Minson, D. (2012). Forage in ruminant nutrition (Vol. 1). New York, NY. Academic Press. 502p.

Nabinger, C., \& Carvalho, P. F. C. (2009). Ecofisiología de sistemas pastoriles: aplicaciones para su sustentabilidad. Agrociencia, 13(3), 18-27.

Nabinger, C., \& Pontes, L. S. (2002). Manejo da desfolha. Simpósio Sobre Manejo da Pastagem, FEALQ, Jaboticabal, p.133-158. 
Nascimento, H. L. B. (2014). Cultivares de Panicum maximum adubadas e manejadas com frequência de desfolhação correspondente a $95 \%$ de interceptação luminosa. Dissertação. (Mestrado em Zootecnia). Universidade Federal de Viçosa. 67f.

Oliveira, P. S. R., Castagnara, D. D., Junior Gonçalves, A. C., Mesquita, E. E., \& Neres, M. A. (2009). Teores de macromineerais em Panicum maximum cvs. Massai e Mombaça. Synergismus Scyentifica, $4(1), 7-10$.

Pena, K. S., Nascimento Júnior, D., Silva, S. C., Euclides, V. P. B., \& Zanine, A. M. (2009). Características morfogênicas, estruturais e acúmulo de forragem do capim-tanzânia submetido a duas alturas e três intervalos de corte. Revista Brasileira de Zootecnia, 38(11), 2127-2136. http://dx.doi.org/10.1590/S1516-35982009001100009

Pereira, O. G., Rovetta, R., Ribeiro, K. G., Santos, M. E. R., Fonseca, D. M., \& Cecon, P. R. (2011). Características morfogênicas e estruturais do capim-tifton 85 sob doses de nitrogênio e alturas de corte. Revista Brasileira de Zootecnia, 40(9), 1870-1878. https://doi.org/10.1590/S1516$\underline{35982011000900005}$

Pereira, V. V. (2013). A importância das características morfogênicas sobre o fluxo de tecidos no manejo de pastagens tropicais. Revista Em Agronegócio e Meio Ambiente, 6(2), 289-309.

Santos, M. R., Fonseca, D. M., Gomes, V. M., Silva, S. P., Silva, G. P., \& Reis, M. (2012). Correlações entre características morfogênicas e estruturais em pastos de capim-braquiária. Ciência Animal Brasileira, 13(1), 49-56. http://dx.doi.org/10.5216/cab.v13i1.13401

Santos, P. M., Balsalobre, M. A. A., \& Corsi, M. (2003). Morphogenetic characteristics and management of Tanzania grass. Pesquisa Agropecuária Brasileira, 38, 991-997. https://doi.org/10.1590/S0100$204 X 2003000800012$.

Santos, P. M., Balsalobre, M. A. A., \& Corsi, M. (2004). Características morfogenéticas e taxa de acúmulo de forragem do capim-mombaça submetido a três intervalos de pastejo. Revista Brasileira de Zootecnia, 33(4), 843-851. http://dx.doi.org/10.1590/S01516-35982004000400004

Sarmiento, G., Silva, M. P., Naranjo, M. E., \& Pinillos, M. (2006). Nitrogen and phosphorus as limiting factors for growth and primary production in a flooded savanna in the Venezuelan Llanos. Journal of Tropical Ecology, 22(2), 203-212. https://doi.org/10.1017/S0266467405003068

Silva, D. J., \& Queiroz, A. C. (2002). Análise de alimentos: métodos químicos e biológicos. Universidade Federal de Viçosa. 305p.

Silva, F. C. (2009). Manual de análises químicas de solos, plantas e fertilizantes. Embrapa Informação Tecnológica. Rio de janeiro. 370p.

Silva, G. S. (2019). Capim Tamani na região amazônica sob adubação nitrogenada e alturas de resíduos. 39 f. Monografia (Bacharelado em Engenharia Agronômica). Universidade Federal da Amazônia. https://doi.org/10.1017/859612000858.

Souza, J. A. S. (2018). Produção de gramineas forrageiras dos gêneros Urochloa $e$ Megathyrsus nas condições edafoclimáticas de Manaus, AM. 58f. Dissertação. (Mestrado em Agronomia Tropical). Universidade Federal do Amazonas.

Tesk, C. R. M., Cavalli, J., Pina, D. S., Pereira, D. H., Pedreira, C. G. S., Jank, L., Sollenberger, L. E., $\&$ Pedreira, B. C. (2020). Herbage responses of Tamani and Quênia guineagrasses to grazing intensity. Agronomy Journal, 201, 1-27. https://doi.org/10.1002/agj2.20189.

Histórico do artigo:

Recebido: 6 de julho de 2021.

Aprovado: 12 de agosto de 2021.
Licenciamento: Este artigo é publicado na modalidade Acesso Aberto sob a licença Creative Commons Atribuição 4.0 (CC-BY 4.0), a qual permite uso irrestrito, distribuição, reprodução em qualquer meio, desde que o autor e a fonte sejam devidamente creditados. 